\title{
Computed tomography and scintigraphy exams for diagnosis and treatment planning of the condylar osteochondroma: A case report
}

\author{
Exames de tomografia computadorizada e cintilografia para \\ diagnóstico e plano de tratamento de osteocondroma condilar: \\ Relato de caso
}

\begin{abstract}
Purpose: To report an uncommon case of osteochondroma affecting the mandibular condyle of a young patient and to illustrate the important contributions of different imaging resources to the diagnosis and treatment planning of this lesion.

Case description: A 24-year-old female patient with the chief complaint of an increasing facial asymmetry and pain in the left pre-auricular region, revealing a reduced mouth opening, mandibular deviation and posterior cross-bite over a period of 18 months. Panoramic radiography revealed an enlargement of the left condyle, whereas computed tomography (CT) sections and three-dimensional CT showed a well-defined bone growth arising from condylar neck. The scintigraphy exam showed an abnormal osteogenic activity in the left temporomandibular joint. The condyle was surgically removed and after 18 months follow-up the panoramic radiography and CT scans showed no signs of recurrence.

Conclusion: Although osteochondroma is a benign bone tumor that rarely arises in cranial and maxillofacial region, it should be considered in the differential diagnosis of slow-growing masses of the temporomandibular area and the use of different imaging exams significantly contribute to the correct diagnosis and treatment planning of this pathological condition.
\end{abstract}

Key words: Osteochondroma; diagnosis; omputed tomography; bone tumors

\section{Resumo}

Objetivo: Relatar um caso incomum de osteocondroma afetando o côndilo mandibular de uma paciente jovem e ilustrar as importantes contribuições dos diferentes exames por imagem para o diagnóstico e plano de tratamento desta lesão.

Descrição do caso: Paciente do sexo feminino, 24 anos, com queixa principal de uma crescente assimetria facial e dor na região pré-auricular esquerda, além de apresentar redução da abertura bucal, desvio de mandíbula e mordida cruzada posterior, por um período de 18 meses. A radiografia panorâmica revelou um aumento do côndilo esquerdo, enquanto secções de tomografia computadorizada e reconstrução 3D exibiram um crescimento ósseo bem definido originando-se do côndilo. $O$ exame de cintilografia revelou uma atividade osteogênica anormal na região de articulação tempormandibular esquerda. $\bigcirc$ côndilo foi cirurgicamente removido e após 18 meses de acompanhamento a radiografia panorâmica e a tomografia computadorizada não revelaram nenhum sinal de recorrência.

Conclusão: Apesar de o osteocondroma ser um tumor ósseo benigno que raramente surge na região crânio maxilofacial, ele deve ser considerado como diagnóstico diferencial para massas de crescimento lento na área temporomandibular e o uso de diferentes exames por imagem contribuem significativamente para o correto diagnóstico e plano de tratamento desta condição patológica.

Palavras-chave: Osteocondroma; diagnóstico; tomografia computadorizada; tumores ósseos

\author{
Fernanda Paula Yamamoto a \\ Brunno Santos de Freitas Silva ${ }^{a}$ \\ Ricardo Wagner Modes ${ }^{b}$ \\ Felipe Paiva Fonseca ${ }^{c}$ \\ Flávia Sirotheau Corrêa Pontes ${ }^{\mathrm{d}}$ \\ Suzana Cantanhede O. M. de Sousa ${ }^{\mathrm{e}}$
}

\begin{abstract}
a Oral Pathology Doctoral Program, University of São Paulo, São Paulo, SP, Brazil

b Dental Service of the Santo André Municipal Hospital Center, Santo André, SP, Brazil

c Department of Oral Diagnosis, Piracicaba Dental School,State University of Campinas, Piracicaba, SP, Brazil

d João de Barros Bareto University Hospital, Federal University of Pará, Belém, PA, Brazil

e Discipline of Oral Pathology, Dental School, University of São Paulo, São Paulo, SP, Brazil
\end{abstract}

\author{
Correspondence: \\ Felipe Paiva Fonseca \\ Madre Cecília Street, 1560 - Centro \\ Piracicaba, SP - Brazil \\ 13400-490 \\ E-mail: felipepfonseca@hotmail.com
}

Received: March 22, 2010

Accepted: September 21, 2010

Conflict of Interest Statement: The authors state that there are no financial and personal conflicts of interest that could have inappropriately influenced their work.

Copyright: (C) 2010 Yamamoto et al. licensee EDIPUCRS. This is an Open Access article distributed under the terms of the Creative Commons AttributionNoncommercial-No Derivative Works 3.0 Unported License. 


\section{Introduction}

Osteochondroma (OC), also known as osteocartilagenous exostosis, is one of the most common benign tumor of long bones, constituting approximately 35 to $50 \%$ of all benign tumors and 8 to $15 \%$ of all primary bone tumors $(1,2)$. However, osteochondromas rarely occurs in oral and maxillofacial regions, where it is more associated with the coronoid process of the mandible and the mandibular condyle $(3,4)$. The pathogenesis of this lesion remains speculative, and discussions about its neoplastic, developmental or reparative nature are frequent (5).

$\mathrm{OC}$ is often a slow growing, progressive deformity (6) and its presentation in mandibular condyle leads to the development of facial asymmetry, malocclusion, cross-bite of the affected side, mouth opening deviation, hypomobility, pain, cliking (1, $2,7)$ and in some cases hearing loss $(8)$. OC is usually diagnosed in older patients with a mean age of 40 years old, showing a female preponderance (1.5:1). In the mandibular condyle region, the radiographic feature of OC is that of an enlarged sclerotic mass that can reach major proportions (5) and the panoramic radiography is considered a screening modality for detection of these lesions.

According to Avinash et al. (9), although OC of the mandibular condyle is a rare pathological condition, it must be distinguished from unilateral condylar hyperplasia, and in these cases the Computed tomography (CT) exam plays a decisive role in differentiating these two entities.

The current report illustrates the contribution of different imaging resources to the diagnosis and treatment planning of an OC affecting the left condyle of a female patient.

\section{Case description}

A 24-year-old female patient was referred to our department with the chief complaint of an increasing facial asymmetry and pain in the left pre-auricular region over a period of 18 months. Clinical examination revealed a reduced mouth opening and a mandibular deviation to the right side producing an evident posterior cross-bite in the affected side (Fig. 1).

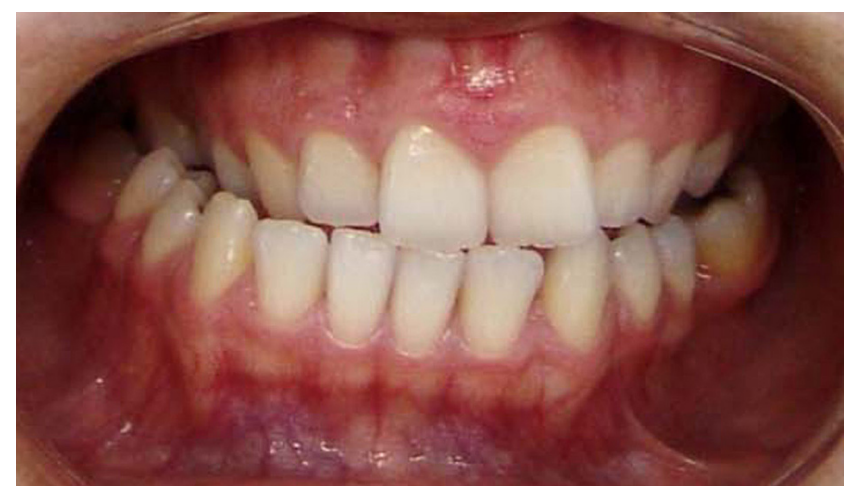

Fig. 1. Frontal view showing a deviation of the mandible to the right side producing an evident posterior cross-bite of the affected side.
Past medical and dental histories were non-contributory and there was no history of facial trauma either.

The panoramic radiography revealed an enlargement of the left condyle with a mushroom-like appearance. However, there were difficulties to distinguish the border limits of the lesion and the normal condyle during radiographic evaluation (Fig. 2A), what required CT exams. Axial and coronal CT sections (Fig. 2B) and three-dimensional CT (Fig. 2C) showed a well-defined bone growth arising from condylar neck extending to the anterior-medial direction. In addition, the continuity of the cortex and medulla of the lesion with the normal condyle could also be observed.
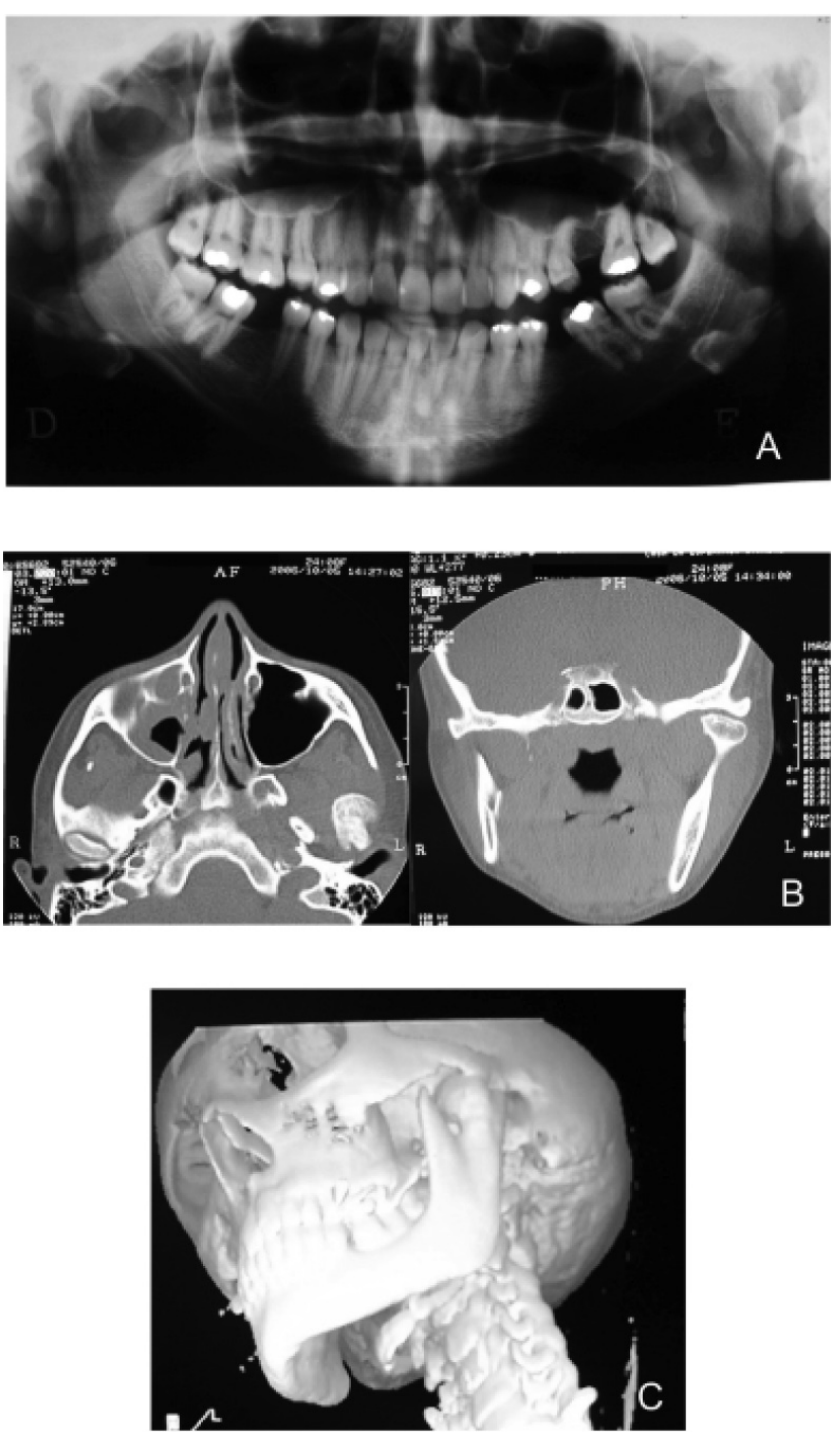

Fig. 2. (A) Panoramic radiography revealing an enlargement of the entire left condyle with a mushroom-like appearance and indistinct borders between the lesion and the normal condyle. (B) Axial and coronal bone window CT sections showing a welldefined bony growth arising from condylar neck presenting continuity of the cortex and medulla of the lesion with the condyle. (C) Three-dimensional CT showing the tumor arising from condylar neck. 
Scintigraphy exam performed previous to the surgery showed an abnormal osteogenic activity in the left temporomandibular joint (TMJ), suggesting an active state of the lesion (Fig. 3).

The condyle was surgically removed via a pre-auricular approach under general anesthesia. The subcutaneous and the muscular tissues were dissected after the cutaneous incision, with subsequent resection of the condyle below the condylar head. The condylar neck reshape was performed and the occlusion was well stabilized using an oclusal splint.

The histopathological examination revealed a hyaline cartilaginous cap, a zone of endochondral ossification, cartilaginous islands in the subcortical bone, and marrow space contiguous with the underlying bone (Fig. 4A and B), confirming the diagnosis of OC.

After surgical treatment, the mandible was placed in a functional relationship using guiding elastics. Six months after the post-operatory rehabilitation the patient was able to perform lateral mandibular movements and an increased mouth opening. After 18 months follow-up, panoramic radiography and $\mathrm{CT}$ scans showed no signs of recurrence (Fig. 5A and B).

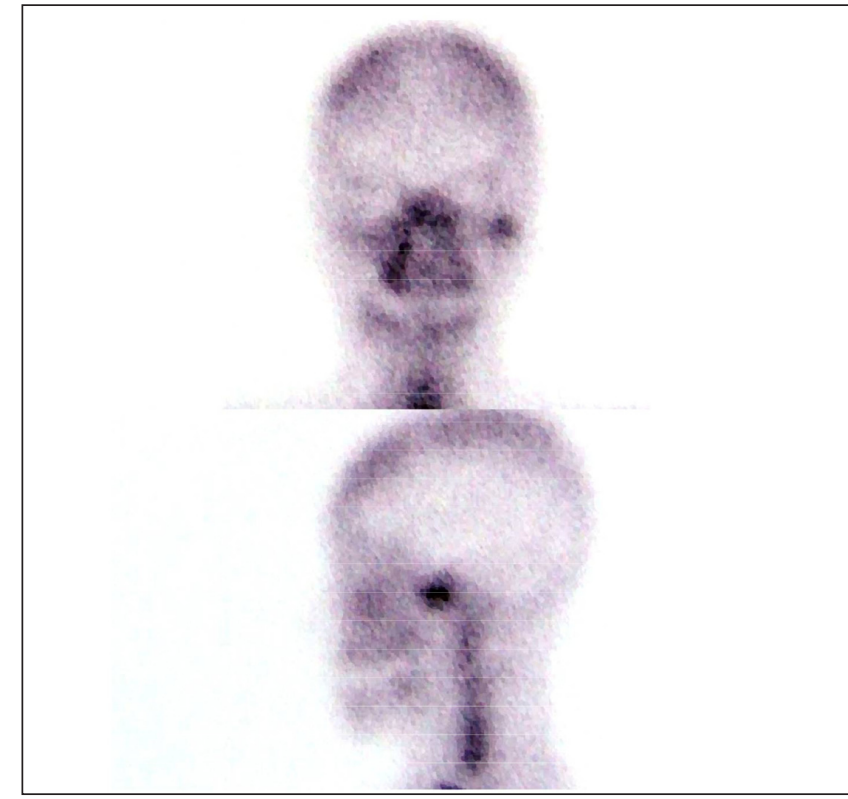

Fig. 3. Bone scintigraphy scan showing an abnormal activity in the left TMJ.
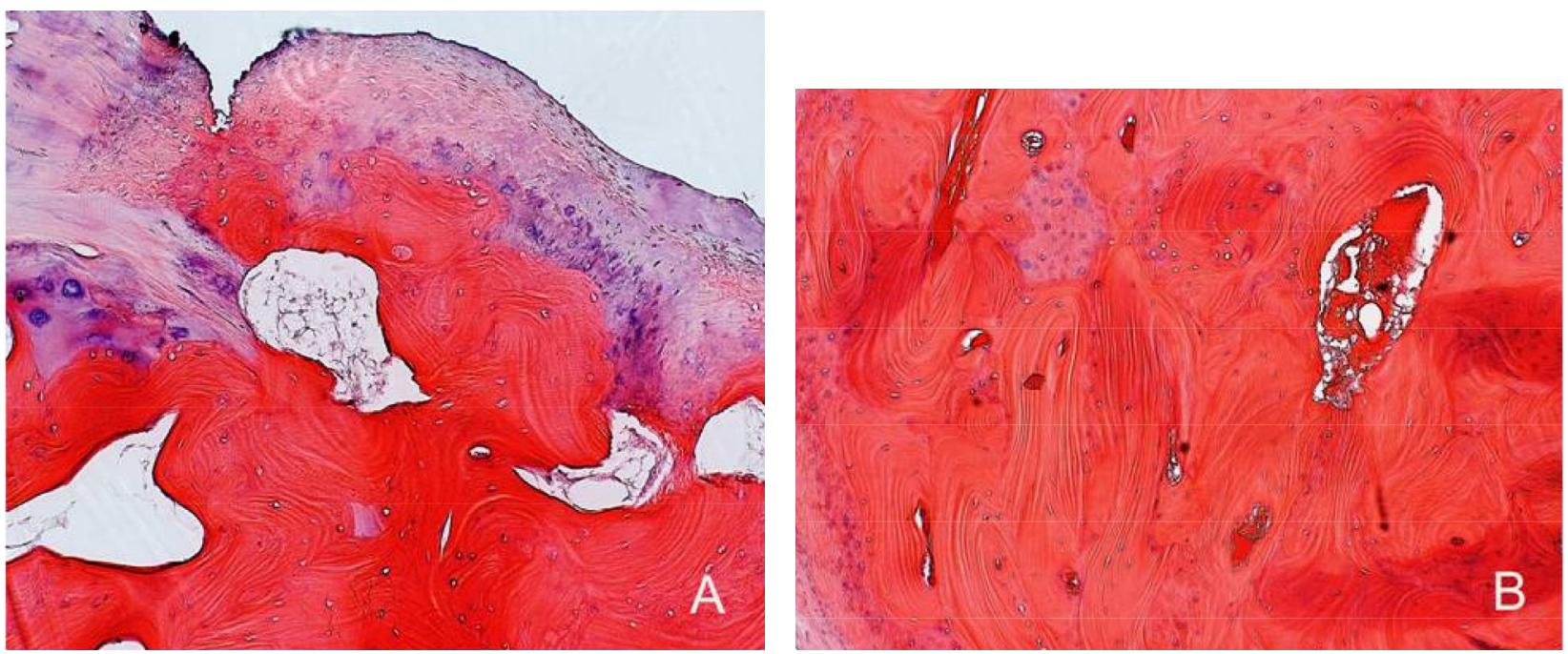

Fig. 4. A) Histopathological examination showing a thin hyaline cap and marrow space (H\&E, original magnification 40x). (B) Cartilaginous islands in the subcortical bone (H\&E, original magnification 100x).
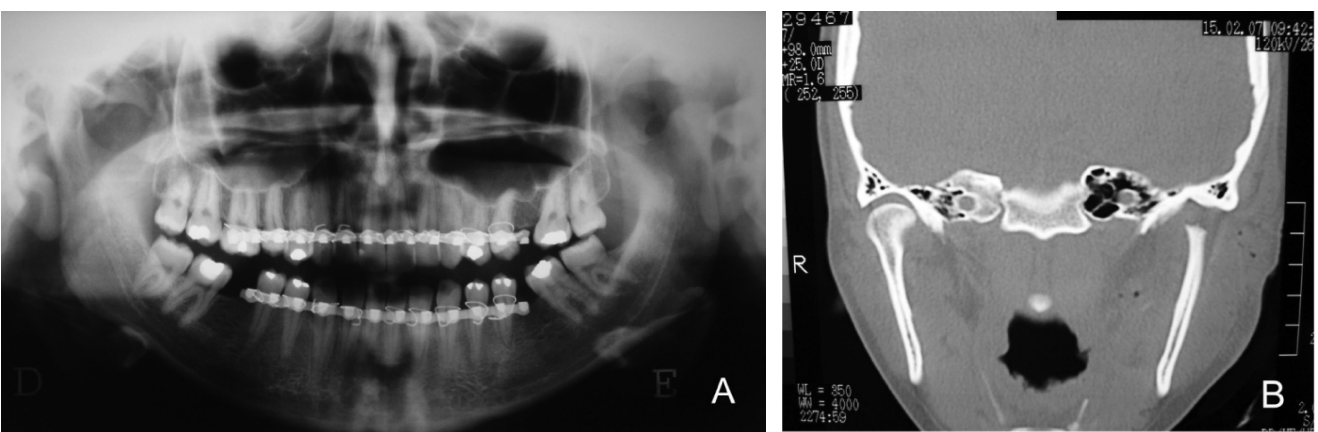

Fig. 5. A) No signs of recurrence in the panoramic radiography.

(B) Coronal bone window CT scan also showing no evidences of recurrence and the right TMJ maintained. 


\section{Discussion}

Many theories concerning the etiology of OC have been performed. The occurrence of these tumors in the mandibular condyle tends to support the theory of aberrant foci of epiphyseal cartilage growth on the surface of bone. It is suggested that stress in the region of tendinous insertion, where focal accumulation of cells with cartilaginous potential exists, would be responsible for the development of these lesions, explaining the $\mathrm{OC}$ occurrence in the coronoid process and condylar region, probably stressed by the tension of the temporal and pterygoid muscles, respectively $(1,2)$. Trauma and inflammation have been implicated as either initiating or predisposing factors (7), however, they are not sufficient to explain all cases of OC (10), including the current case, in what the patient did not report any history of local trauma.

Histopathological examination of $\mathrm{OC}$ reveals a cartilaginous cap similar to that seen in the normal growing cartilage, endochondral ossification, cartilaginous islands in the subcortical bone and marrow spaces contiguous with the underlying bone. However, it tends to be thinner in maxillofacial region and may even be absent in long-standing cases (2), causing some diagnostic difficulties.

Condylar OC, though a rare entity, should be considered in the differential diagnosis of slow-growing masses in the temporomandibular region (10), and must be mainly distinguished from condylar hyperplasia (9). Radiographically, OC presents a nodular or a mushroom-like shape in most of the cases $(2,4)$. In panoramic radiographs, the borders between the lesion and the normal condyle, a necessary feature for the diagnosis of OC, are sometimes difficult to be distinguished (9) and the establishment of an initial diagnosis may be a dilemma for the surgeon (2).

Zhang et al. (4) showed a great diversity of condylar OC shapes, making it more difficult to distinguish from condylar hyperplasia in plain radiographs. CT may help to delineate the anatomy of the lesion, providing excellent bony details (4) and playing a decisive role in differentiating the two entities, once $\mathrm{OC}$ is seen arising from a morphologically normal condyle with the maintenance of the normal outline of the condylar head (9), whereas condylar hyperplasia is seen as an enlargement of the condylar process (11). CT also supplies an invaluable support during the evaluation and the treatment planning of these tumors $(2,6)$, where three-dimensional reconstruction serves as an adjunct to CT exam, providing surgeons with a more global perspective in cases of large tumors (12).

Panoramic radiographs were responsible for some doubts about the OC features in the present case, in part due to possible distortions inherent to the technique. Therefore, CT scans must be considered important complementary exam, offering subsidies for OC diagnosis (13).
Bone scintigraphy is an accepted method for visualizing hyperactivity in condyle (14). In the present case the planar scintigraphy confirmed a significant higher diphosphonate uptake in the left condyle, providing additional information about the active state of the lesion. A large difference in condylar scintigraphy activity might be indicative to a direct resection of the lesion (14).

Conservative approaches such as the high condylectomy technique (with the removal of the top 3 to $4 \mathrm{~mm}$ of the condylar head) usually stops further growth in patients with condylar hyperplasia, but seems to be insufficient in the treatment of OC (2). Condylectomy may be the treatment of choice of this pathological condition, once this surgical technique provides an easier and safer removal of the lesion when important structures are concerned (15) and it is possibly related to a lower rate of recurrence. However, condylectomy cannot be recommended as routine in all cases because its known disadvantages, such as loss of vertical dimension, shifting of the occlusal plane, and dysfunction of the contralateral unaffected TMJ caused by deleterious effects of unphysiologic stress distribution (15). In the current case the patient underwent the resection of condyle $3 \mathrm{~mm}$ below the condylar head in a region visually without lesion, followed by a condylar neck reshape, aiming to reduce possible disadvantages of condylectomy.

The literature reveals different treatment approaches in cases with clinical evidences of OC of the condyle. However, due to the difficulty of performing the biopsy of the lesion and getting the definitive histopathological diagnosis previously to the treatment and because the imaging resources are not usually used to their fullest, there is a possibility of selecting an inappropriated surgical technique for these tumors. Therefore, in spite of the OC evidences offered by the CT scans, the use of bone scintigraphy was very important in this case to select the most appropriate treatment modality, once it revealed that a conservative technique would not be indicated due to the hyperactivity of the affected region.

The current article reveals that several parameters are needed to make $\mathrm{CT}$ a valuable resource for the diagnosis of mandibular OC. Besides, in contrast to the general literature that emphasizes only the use of the computed tomography exam for the diagnosis of $\mathrm{OC}$, this paper shows evidences of the great contribution offered by the bone scintigraphy, not only as auxiliary in the diagnosis of osteochondroma, but also in the treatment planning of the lesion. Taking together, these imaging resources must be considered important tools for helping the professional to reach the correct diagnosis and the most adequate treatment approach for $\mathrm{OC}$ of the mandibular condyle.

In conclusion, a reliable diagnosis of $\mathrm{OC}$ is necessary to establish a more appropriate treatment and, therefore, CT evaluation, three dimensional reconstruction and bone scintigraphy should be performed routinely in suspected cases of OC of the condyle. 


\section{References}

1. Ortakoglu K, Akcam T, Sencimen M, Karakoc O, Ozyigit A, Bengi O. Osteochondroma of the mandible causing severe facial asymmetry: a case report. Oral Surg Oral Med Oral Pathol Oral Radiol Endod 2007; 103:e21-e28.

2. Wolford LM, Mebra P, Franco P. Use of conservative condylectomy for treatment of osteochondroma of the mandibular condyle. J Oral Maxillofac Surg 2002;60:262-8.

3. Henry CH, Granite EL, Rafetto LK. Osteochondroma of the mandibular condyle: report of case and review of the literature. J Oral Maxillofac Surg 1992;50:1 102-8.

4. Zhang J, Wang H, Li X, Li W, Wu H, Miao J, et al. Osteochondroma of the mandubular condyle: a variance in radiographic appearance on panoramic radiographs. Dentomaxillofac Radiol 2008;37: 154-60.

5. Peroz I, Scholman HJ, Hell B. Osteochondroma of the mandibular condyle: a case report. Int J Oral and Maxillofac Surg 2002;31:455-6.

6. Ward BB, Pires CAS, Feinberg SE. Osteochondroma of the mandible: a case report and rationale for treatment. J Oral Maxillofac Surg 2005;63:1039-44.

7. Gaines RE, Lee MB, Crocker DJ. Osteochondroma of the mandibular condyle: case report and review of the literature. J Oral Maxillofac Surg 1992;50:899-903.
8. Seki H, Fukuda M, Takahashi T. Condylar osteochondroma with complete hearing loss: report of a case. J Oral Maxillofac Surg 2003;61:131-3.

9. Avinash KR, Rajagopal KV, Ramakrishnaiah RH, Carnelio S, Mahmood NS. Computed tomographic features of mandibular osteochondroma. Dentomaxillofac Radiol 2007;36:434-6.

10. Vezeau PJ, Fridrich KL, Vincent SD. Osteochondroma of the mandibular condyle: literature review and report of two atypical cases. J Oral Maxillofac Surg 1995;53:954-63.

11. Nitzan DW, Katsnelson A, Bermanis I, Brin I, Casap N. The clinical characteristics of condylar hyperplasia: experience with 61 patients. J Oral Maxillofac Surg 2008;66:312-8.

12. Horward JD, Elster AD, May JS. Temporal Bone: three-dimensional CT. Radiology 1990; 177:427-30.

13. Holmung AB, Gynther GW, Reinholt FP. Surgical treatment of osteochondroma of the mandibular condyle in the adult: a 5-year follow-up. Int J Oral Maxillofac Surg 2004;33:549-33.

14. Saradin CP, Rajmakers P, Becking AG. Quantitative analysis of planar bone scintigraphy in patients with unilateral condylar hyperplasia. Oral Surg Oral Med Oral Pathol Oral Endod 2007;104:259-63.

15. Aydin MA, Kuçukçelebi A, Sayilkan S, Çelebioglu S. Osteochondroma of the mandibular condyle: report of 2 cases treated with conservative surgery. J Oral Maxillofac Surg $2001 ; 59: 1082-9$. 